\title{
Changes in Fish Catch Rates in the Presence of Air Gun Sounds in Prudhoe Bay, Alaska

\author{
Bill Streever, ${ }^{1}$ Scott W. Raborn, ${ }^{2}$ Katherine H. Kim, ${ }^{3}$ Anthony D. Hawkins ${ }^{4}$ and Arthur N. Popper ${ }^{5}$
}

(Received 4 January 2016; accepted in revised form 29 June 2016)

\begin{abstract}
Air guns used in oil industry seismic surveys have the capacity to change fish catch rates, but no previous work has demonstrated this effect in shallow water or in Arctic oilfields. Long-term monitoring of fish catches using four fyke nets allowed assessment of changes in catch rates during a 2014 seismic survey in Prudhoe Bay, Alaska. Fyke net locations were instrumented with both conventional hydrophones and vector sensors. Catch rates were generally within the range of those found in 27 previous sampling seasons. The effect of air guns on eight species was assessed using a modified Before-After/ Control-Impact analysis, with historical data and 2014 data as the Before-After components of the analysis and days without and with air gun activity as the Control-Impact components. Results showed significant changes associated with air guns in catch rates at one or more nets at $p<0.1$ for all eight species and at $p<0.05$ for seven of the eight. Changes included both increased and decreased catch rates, perhaps reflecting displacement of fish in response to air gun sounds throughout the study area. Measured sound pressure levels associated with air gun pulses were low and usually undetectable close to the fyke nets, reflecting the loss of low frequencies in shallow water $(\sim 1.5 \mathrm{~m})$. Attempts to measure particle velocities failed when wind-driven surface waves overwhelmed vector sensors. However, fish responses may have been related to changes in particle motion associated with air gun sounds.
\end{abstract}

Key words: sound and marine life; air guns; fish; seismic; Before-After/Control-Impact; Alaska; Prudhoe Bay oilfield

RÉSUMÉ. Les armes à air comprimé dont on se sert pour faire les levés sismiques dans l'industrie pétrolière ont la capacité de changer le taux de capture des poissons, mais aucune étude n'a jamais démontré l'effet de ces armes dans les eaux peu profondes ou dans les champs pétrolifères de l'Arctique. La surveillance à long terme des prises de poissons à l'aide de quatre verveux a permis d'évaluer les changements en matière de taux de prises pendant un levé sismique qui a eu lieu à Prudhoe Bay, Alaska, en 2014. Les emplacements de verveux ont été munis d'hydrophones classiques et de capteurs de vecteur. De manière générale, les taux de prises coïncidaient avec la gamme répertoriée au cours des 27 saisons d'échantillonnage précédentes. L'effet des armes à air comprimé sur huit espèces a été évalué au moyen d'une analyse modifiée avant-après/contrôle-impact, les données historiques et les données de 2014 représentant les composantes avant-après de l'analyse, puis les jours avec et les jours sans activité d'armes à air comprimé représentant les composantes contrôle-impact de l'analyse. Les résultats ont permis de constater d'importants changements liés à l'emploi d'armes à air comprimé pour ce qui est des taux de prises à un ou plusieurs verveux, à $p<0,1$ pour les huit espèces, et à $p<0,05$ pour sept des huit espèces. Les changements se sont caractérisés à la fois par des taux de prises plus élevés et moins élevés, ce qui reflétait peut-être le déplacement des poissons en raison du son des armes à air comprimé dans la zone visée par l'étude. Les niveaux de pression sonore mesurés en lien avec les impulsions d'armes à air comprimé étaient faibles et habituellement indétectables à proximité des verveux, signe de la perte des ondes kilométriques dans l'eau peu profonde $(\sim 1,5 \mathrm{~m})$. Les tentatives de mesure des vitesses acoustiques des particules ont échoué lorsque les ondes de surface poussées par le vent submergeaient les capteurs de vecteur. Toutefois, la réaction des poissons aurait pu être liée aux changements sur le plan du mouvement des particules découlant du son des armes à air comprimé.

Mots clés : son et vie marine; armes à air comprimé; poisson; séismique; avant-après/contrôle-impact; Alaska; champ pétrolifère de Prudhoe Bay

Traduit pour la revue Arctic par Nicole Giguère.

\footnotetext{
${ }^{1}$ Corresponding author: BP Exploration, Alaska, Inc., 900 East Benson Boulevard, Anchorage, Alaska 99519, USA;

current address: LAMA Ecological, 3824 Cedar Springs Road \#801-2771, Dallas, Texas 75219, USA; Bill@lamaecological.com

${ }^{2}$ LGL Ecological Research Associates, Inc., 4103 South Texas Avenue, Suite 211, Bryan, Texas 77802, USA

${ }^{3}$ Greeneridge Sciences, Inc., 90 Arnold Place, Suite D, Santa Barbara, California 93117, USA

${ }^{4}$ Loughine Ltd., Kincraig, Blairs, Aberdeen AB12 5YT, United Kingdom

${ }_{5}^{5}$ Department of Biology, University of Maryland, College Park, Maryland 20742, USA \& Environmental BioAcoustics LLC, Silver Spring, Maryland 20906, USA

(C) The Arctic Institute of North America
} 


\section{INTRODUCTION}

Offshore industrial activities generate underwater sounds with the potential to affect marine life, including fishes (Southall et al., 2007; Hastings, 2008; Popper and Hastings, 2009; Hawkins and Popper, 2014; Hawkins et al., 2014; Popper and Hawkins, 2016). Air guns used in seismic surveys to map geological features, including features associated with oil and gas deposits, have drawn attention because of their output of high amplitude, lowfrequency sounds and their pervasive presence in the world's offshore oilfields (Richardson et al., 1995; Southall et al., 2007; Nowacek et al., 2015). Close to active air guns, impacts on fishes potentially include physical injury and even mortality. Although mortality has never been recorded under field conditions, inner ear damage has been documented in one fish species (McCauley et al., 2003), but not in several others (Song et al., 2008). Temporary hearing loss following exposure to sound has also been found for some species (Popper et al., 2005). At distances of thousands of meters, where sound levels are usually lower but sounds are still potentially audible, fishes may show changes in behavior (Engås et al., 1996; Wardle et al., 2001; Engås and Løkkeborg, 2002; Løkkeborg et al., 2012; Hawkins et al., 2015). The nature and extent of behavioral changes are likely to vary with factors such as air gun duty cycles and received sound pressure levels, particle velocities, and frequencies, as well as species, life stage, health and physiological state, ambient sound levels, previous experience with similar sounds, and other factors (Hawkins et al., 2014; Popper et al., 2014). Behavioral changes may range from apparently inconsequential startle responses (McCauley et al., 2000; Wardle et al., 2001) to abandonment of feeding and breeding sites. Air gun sounds have been associated with decreased catch rates, which could be caused by gross displacement of fishes that possibly interfere with access to food or refugia and affect established fisheries (Skalski et al., 1992; Engås and Løkkeborg, 2002). Likewise, air gun sounds severely affected the distribution, local abundance, and catch rates of cod and haddock (Engås et al., 1996). Seismic investigations in an area off western Norway showed that the acoustic abundance estimate for pelagic fish was higher outside than inside the seismic shooting area, indicating a long-term effect of the seismic activity (Slotte et al., 2004). Both the herring and blue whiting in that study were examined during a large-scale feeding migration. However, very little is actually known about the detailed effects of air guns or other loud sound sources on fish behavior.

Sound pressure levels experienced by fishes vary not only with source levels and distance from sources, but also with environmental conditions. Changes in water depth have a substantial effect on sound propagation through the water column. Although air guns generate broadband sounds, their highest sound energies are found at frequencies below $1 \mathrm{kHz}$, and there is a low-frequency cutoff phenomenon for sound pressure in very shallow water
(Kinsler et al., 1982; Greene, 1987; Greene and Richardson, 1988; Rogers and Cox, 1988; Richardson et al., 1995; Jensen et al., 2000). For example, in water depths of less than $1.5 \mathrm{~m}$ over soft bottom sediments, sound pressures at frequencies below roughly $700-800 \mathrm{~Hz}$ propagate very poorly through the water column. However, fishes close to the seabed may detect particle motion associated with low-frequency sounds propagating through the seabed.

Most studies that have measured sound levels to assess the potential effects of sounds on marine life have considered only sound pressure levels and associated metrics (such as sound exposure levels), while ignoring other components of underwater sound, including particle motion (i.e., the displacement or acceleration of the fluid particles that make up the water column). The emphasis on sound pressure levels and the general neglect of particle motion probably reflect the ready availability of hydrophones, which measure sound pressure directly, and the comparative unavailability of vector sensors or other instruments capable of reliably measuring particle motion (Pangerc and Theobald, 2014; Hawkins et al., 2015). Although it is easy to estimate particle velocities from sound pressures under plane-wave conditions, the relationship between sound pressures and particle velocities is more complex in shallow water, where it is influenced by boundaries such as the sea surface, which forms a pressure-release surface, and the seafloor, where seismic interface waves can increase levels of particle motion (Hovem, 2014; Hazelwood and Macey, 2016; Rogers et al., 2016).

Despite challenges associated with measuring particle motion and the ease with which sound pressure can be measured, it is likely that most fish species are sensitive to particle motion, while only some species are sensitive to sound pressure (Popper and Fay, 2011). It follows that particle motion is probably more important than sound pressure as a stimulus capable of eliciting detectable behavioral responses in many fish species. This reality is especially important in shallow water, for example, along the waterbottom interface, where sound pressure levels associated with low-frequency sources such as air guns may be low or undetectable even though particle velocities might remain elevated because of ground roll (Rayleigh) waves.

Our study took advantage of proximity to a shallowwater geophysical survey area where daily summertime fish sampling at four fyke net locations has been done for 28 years (McCain and Raborn, 2015). This previous work offered an opportunity to assess the degree to which underwater sounds from air guns might be associated with gross behavioral changes in shallow water fish, expressed as changes in catch rates. An adaptation of the Before-After/ Control-Impact (BACI) study design allowed us to compare fish catches with and without air gun activity in 2014 to historical catch rates, while data from hydrophones and vector sensors placed at each net offered insight into the sounds received at the fyke net locations. 


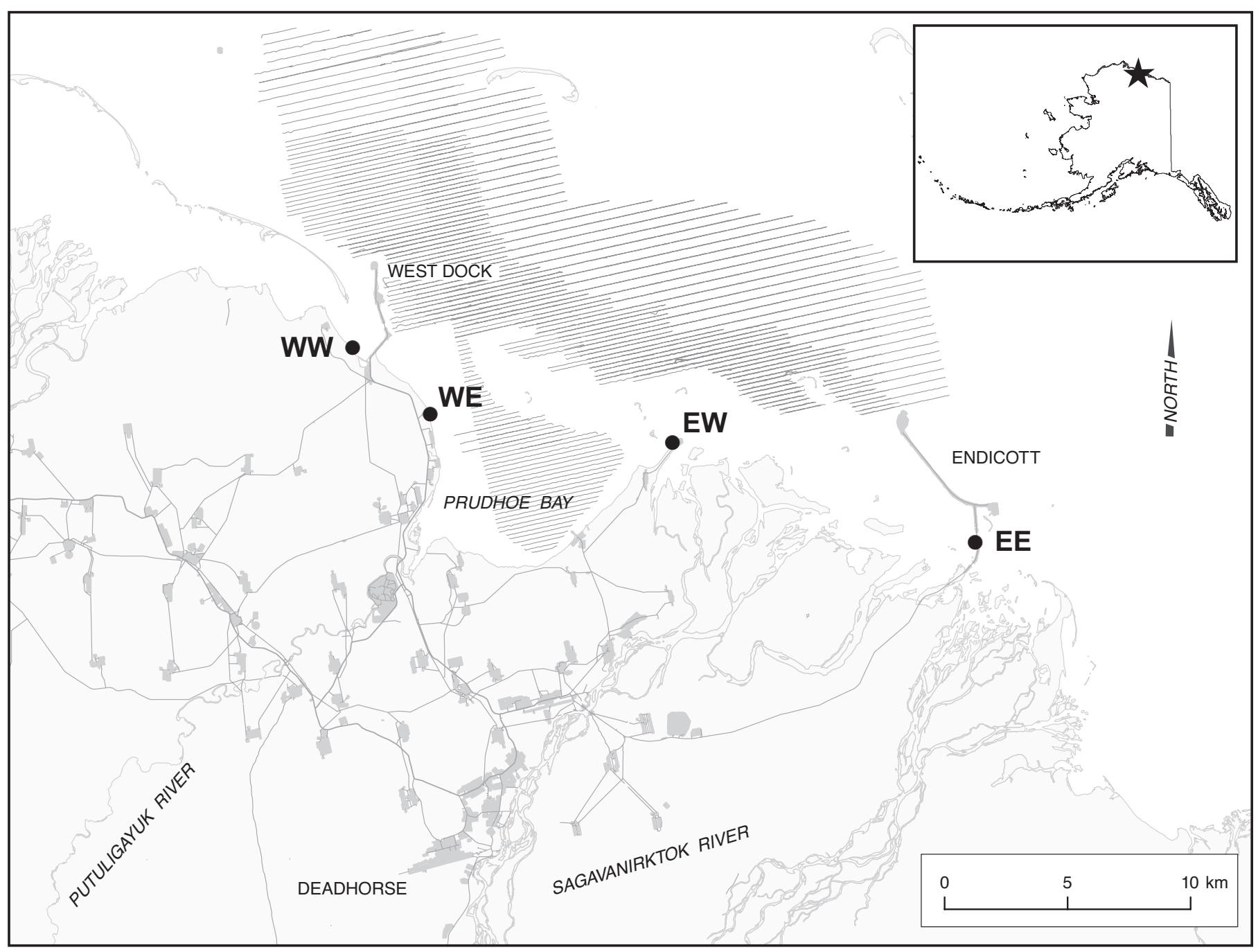

FIG. 1. Fyke net locations (WW, WE, EW, and EE) with lines (running approximately east and west) indicating shot lines for air gun arrays. Endicott and West Dock are solid fill (rock and gravel) causeways with breaches for fish passage.

\section{METHODS}

\section{Study Area}

The study was carried out in the nearshore waters of Prudhoe Bay, Alaska (Fig. 1). From the intertidal zone to about $10 \mathrm{~km}$ offshore, water depths gradually increase to $16 \mathrm{~m}$. Freshwater enters the study area primarily from discharge of the Sagavanirktok River. Close to shore, salinity varies from 0 to $33 \%$ and water temperature during the sampling season ranges from $3^{\circ} \mathrm{C}$ to $14^{\circ} \mathrm{C}$ (McCain and Raborn, 2015). Water temperatures tend to decrease and salinities increase during periods of sustained east winds, which create upwelling along the coast. The shore of the study area is lined with industrial infrastructure, including oil production facilities and roads. Near the western boundary of the study area, a gravel causeway with two breaches intended for fish passage extends offshore to a distance of about $4.3 \mathrm{~km}$. Near the eastern boundary of the study area, another gravel causeway with three breaches intended for fish passage extends offshore $4.8 \mathrm{~km}$ before dividing into two arms, with a northwestern arm extending an additional $6.8 \mathrm{~km}$ and an eastern arm extending about $0.9 \mathrm{~km}$ farther.

\section{Sampling Fishes and Environmental Variables}

Fishes were sampled using fyke nets at four locations adjacent to the shore from 1985 until 1998 and from 2001 until 2014, for a total of 28 years. Fyke nets-essentially large fish traps - consisted of paired stainless steel frames, $1.7 \mathrm{~m}$ by $1.8 \mathrm{~m}$, each supporting a cod-end net of $1.3 \mathrm{~cm}$ stretched mesh (Fig. 2). A single leader $60 \mathrm{~m}$ long with $2.5 \mathrm{~cm}$ mesh extended offshore from the center of each fyke net, and wings $15 \mathrm{~m}$ long with $2.5 \mathrm{~cm}$ mesh extended outward from each side of each net. Fyke net openings were oriented toward shore, so that fishes swimming along the shore encountered the leads and were guided into nets. Water depth at the fyke nets was typically about $1.2 \mathrm{~m}$, but varied from about 0.5 to $1.5 \mathrm{~m}$ with changing winds and tides.

From about 1 July until 31 August each year, nets were checked daily when conditions allowed. Occasionally, 


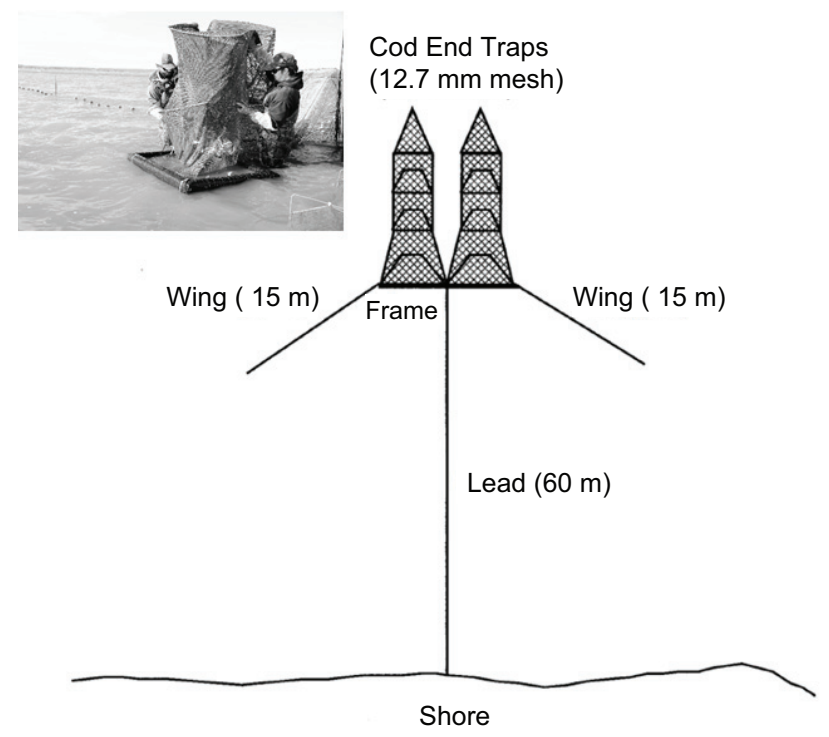

FIG. 2. Four fyke nets, one at each site, have been used to monitor nearshore fish near Prudhoe Bay for more than 30 years. Inset shows two biologists collecting fish from the fyke net in a portable holding pen. Diagram is not to scale.

sampling had to be suspended because of ice, inclement weather, or the presence of polar bears. Fishes from nets were identified to species and sized before being released. Two of the most abundant species, Arctic cisco (Coregonus autumnalis) and broad whitefish (C. nasus), were categorized by age classes based on length-frequency histograms. For the purposes of this study, fishes caught from each side of the lead at each fyke net were pooled. Fish abundance was normalized as catch per unit effort (CPUE), with effort determined by the number of hours between sampling events (typically about $24 \mathrm{~h}$ ). Individual samples consisted of one day's catch for each net.

We calculated daily discharge rates from river discharge data measured at United States Geological Survey gauging station 15908000 in the Sagavanirktok River. These discharge rates affect salinity in the nearshore region, especially near the river channel outlets at the eastern side of the study area. Wind data collected by the U.S. National Weather Service at the nearby Deadhorse Airport provided hourly average wind speed and direction.

\section{Seismic Survey in the Study Area}

Offshore seismic surveys during the open water season are common in the Alaskan Beaufort Sea, but no seismic surveys were conducted in the study area during the icefree season from 1981 to the end of 2013. During summer 2014, a geophysical survey was conducted in the study area (see Fig. 1), with air gun activity commencing on 24 July and continuing intermittently until 25 August. Air gun array characteristics are listed in Table 1. Typically, two source vessels, traveling at $\sim 9.25 \mathrm{~km} / \mathrm{h}$, each towed an air gun array. Source vessels worked in tandem when operational conditions allowed, with each vessel firing at $16 \mathrm{~s}$
TABLE 1. Characteristics of air gun arrays used in the geophysical survey conducted near the study area from 24 July to 25 August in 2014.

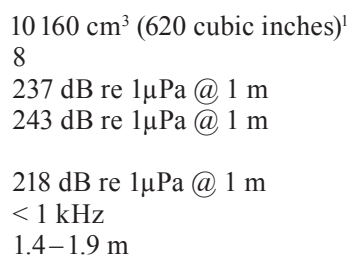

\footnotetext{
${ }^{1}$ Air gun array volumes, by convention, are described in cubic inches.
}

intervals with an $8 \mathrm{~s}$ offset, so that an air gun array was fired from one vessel or the other every $8 \mathrm{~s}$. When conditions restricted operations to a single vessel, air guns were fired every 12 to $14 \mathrm{~s}$. Weather conditions stopped air gun operations on 2 August and 8-16 August. Stoppages of less than $24 \mathrm{~h}$ occurred intermittently throughout the survey as the result of weather, logistical issues, and the presence of marine mammals within pre-established mitigation zones.

\section{Acoustic Measurements in 2014}

At each fyke net, sound pressure levels were measured using Autonomous Submersible Acoustic Recorders, or ASARs (Model ASAR-Cs built by Greeneridge Sciences, Inc.), from 13 July until 29 August 2014. ASARs were placed within about $15 \mathrm{~m}$ of fyke nets in water depths of about $1.2 \mathrm{~m}$. Each ASAR was equipped with two omnidirectional sound pressure sensors of different sensitivities $(-230$ and $-160 \mathrm{~dB} \mathrm{~V} / \mu \mathrm{Pa}$ sensitivities over the $0.01-50 \mathrm{kHz}$ frequency band), enabling measurement of very high sound pressure levels received from nearby air guns and much lower sound pressure levels received from more distant air guns. ASARs were programmed to record at a $24 \mathrm{kHz}$ sampling rate, providing a record of sound pressures ranging in frequency from $10 \mathrm{~Hz}$ to about $12 \mathrm{kHz}$. Acoustic data from ASARs at each net were processed to yield multiple metrics, each summarizing aspects of the sound pressure levels of air gun pulses received during each fishing day (i.e., each period between checking fyke nets, typically about $24 \mathrm{~h}$ ). These metrics included maximum root-mean-square sound pressure level (SPL), greatest sound exposure level (SEL) of any air gun pulse, cumulative SEL from all air gun pulses, and equivalent continuous noise level (Leq) of air gun pulses or cumulative SEL/ cumulative time of pulses.

In addition, Directional Autonomous Seafloor Acoustic Recorders or DASARs (Model C08 DASAR-Cs built by Greeneridge Sciences, Inc.) capable of measuring horizontal particle velocity were placed at each fyke net. Like the ASARs, the DASARs were deployed at a depth of about $1.2 \mathrm{~m}$ and recorded from 13 July until 29 August 2014. Each DASAR was equipped with one omnidirectional pressure sensor (sensitivity of $149 \mathrm{~dB}$ re $1 \mathrm{~V} / \mu \mathrm{Pa}$ at 
$100 \mathrm{~Hz}$ ) and a pair of orthogonal directional sensors, which measured acoustic particle motion along the two horizontal axes. Each DASAR collected data at a $1 \mathrm{kHz}$ sampling rate on each of its sensors, which, after allowing for antialiasing, results in a usable frequency band of $10-450 \mathrm{~Hz}$. Although full characterization of particle velocity requires particle motion sensors mounted in three orthogonal directions, the DASARs available to this project were deployed in the hope that measurement of only the horizontal components would be adequate under these very shallow water conditions. Data from DASARs at each net were processed to yield estimates of particle velocity, such as root-meansquare sound [particle] velocity level (SVL) and maximum SVL, as well as various metrics to quantify the degree of clipping; that is, measurements that exceeded the maximum signal the hardware could support without distortion.

\section{Data Analyses}

This field experiment was opportunistic in that the 2014 seismic survey happened to occur in close proximity to a long-term fish monitoring study. In this regard, sampling was purposive because sites could not be randomly selected in relation to the seismic survey grid. Nevertheless, the historical time series of catch and environmental data from the four fyke net sites provided a baseline for comparison with the 2014 catch patterns.

Dependent Variables: Analyses targeted CPUE for a subset of species and size classes chosen because of their numerical dominance, ecological importance, or socioeconomic importance, or to cover the ranges of variation in anatomy and vertical position in the water column that may influence how species respond to sounds. Although Arctic cod (Boreogadus saida) is an important subsistence fishery species and occasionally very abundant, it was excluded from the analyses because of extreme interannual variability in CPUE. Arctic cisco age 0 were excluded from the analyses because their distribution is largely dependent on wind-driven currents rather than intentional horizontal movement.

Experimental Design: Many determinants could have influenced catch rates of the various species to cause fluctuations across sites, days, and years. Terms, or independent variables, were added to a statistical model that accounted for much of this variability. Once parameters for these terms were estimated, each term could then be held constant so that the effect of seismic disturbance could be tested.

The familiar Before-After/Control-Impact (BACI) design can provide definitive evidence concerning environmental impacts, in part by guarding against the possibility that some unknown influence varied across samples in such a way as to bias estimation of the impact in question (Hurlbert, 1984; Underwood, 1991; Smith, 2002). To create this design, terms are added to the model that parse the samples into the four BACI cells: BC, BI, AC, and AI. Holding all other terms constant, the model outputs predict CPUE values for each of these cells. These values are used to determine whether the relationship of the before and after periods is different for the control cells vs. the impact cells.

Conventional BACI study designs rely on control sites believed to be unaffected by the putative impact. In this study, all four sites were close enough to the air gun survey to be potentially affected, but air guns were not fired on 41 of the 58 sampling days during the 2014 season. Samples consisted of CPUE for each day for each net. The categorical variable $B A$ separated the data into two nominal levels, Historical (or "before") and 2014 (or "after"), while the categorical variable $C I$ separated the 2014 data into two additional nominal levels, days without air gun activity ("control") and days with air gun activity ("impact"). The same Julian dates designated as either Control or Impact in 2014 were categorized as such in previous years, even though no seismic disturbance occurred in the historical dataset. Thus, a significant interaction term for $B A \times C I$ would indicate that the seasonal patterns in CPUE across Control and Impact days were not consistent between the historical and 2014 data.

Independent Variables and Model Specification: Categorical variables available for explaining variation in CPUE of the various species included Year and Site and the two seismic disturbance variables described above, $B A$ and $C I$. Available covariates (continuous variables) influential upon CPUE included east-west and north-south wind components (Cartesian coordinates; $x$-axis values quantified the east-west component, Wind-X, and y-axis values the northsouth component, Wind-Y), Julian date (henceforth referred to as Day), and Sagavanirktok River discharge (SRD).

The final analytical approach was derived based on a series of questions concerning (1) which distribution to assume for the response variables, (2) how to model correlation among samples adjacent in time and space, (3) how the random effects were defined, and (4) how fixed effects of the model were specified. The same decisions for questions 1-4 were used for all dependent variables. Convergence of parameter estimates failed for varying combinations of answers to these questions, preventing the use of multimodel inference such as the information theoretic approach suggested by Burnham and Anderson (2002). Many specifications failed to converge during the numerical search for parameter solutions or produced non-estimable confidence intervals because of unbalanced or missing data and the high percentage of zeroes. Other specifications were overparameterized, resulting in unrealistic confidence intervals, or simply had poor model fits.

For Question 1, the negative binomial regression was selected, which accounted for overdispersion and used the log link function to portray the predicted catches:

$$
\log _{\mathrm{e}}\left(\lambda_{i} \cdot \omega_{i}\right)_{=} \mu+x_{i} \beta+z_{i} b
$$

where $\lambda_{i}=$ predicted CPUE for the $i$ th year-day-site combination, $\omega_{i}=$ effort offset (net soak time in days), $\mu=$ overall mean, $x_{i}=$ the vector of fixed effects, $\beta=$ their corresponding 
vector of coefficients, and $z_{i}$ and $b=$ the random effects and coefficients. This two-parameter discrete distribution is commonly used for analysis of CPUE data to handle overdispersion and the typically high frequency of zero catches (Terceiro, 2003; Minami et al., 2007; Arab et al., 2008; Shono, 2008; Dunn, 2009). Multiplying each predicted CPUE $\left(\lambda_{i} \cdot \omega_{i}\right)$ by the effort offset made each prediction comparable to observed catches for likelihood estimation and forced each sample to be weighted by its soak time.

Questions 2 and 3 concerned how to model the covariance structure of the data. Autocorrelation occurred across consecutive Days, and the general seasonal patterns in CPUE varied randomly across Years and Sites. With Gaussian data, autocorrelation is often dealt with via the addition of an auto regression process of lag $=1$, known as an AR(1) process. However, for two-parameter, non-Gaussian distributions (e.g., the negative binomial), variance for the AR(1) parameter is not identifiable from and competes with the scale parameter of the distribution. "Overfitting" the covariance structure can cause a dramatic loss of power to detect differences in the fixed effects (Stroup, 2013). Finally, convergence of parameter estimates is often not possible when modeling autocorrelation in concert with other random effects. Modeling the discrete nature of the data, combined with accounting for random variation in CPUE across years and nets, took priority. Ultimately, the final model specification represented the current state of knowledge in addressing the statistical issues that arose when analyzing these data. The large effect sizes (see Results) mitigated potential bias in the conclusions caused by autocorrelation.

Finally, the rationale for the way we specified fixed effects (Question 4) was as follows. The seasonal pattern in CPUE for all responses was never linear. Therefore, the linear assumption was relaxed by specifying Day as a continuous variable fit using a B-spline with one equally spaced knot (degree $=3$ within each knot segment). The effect of this term, splDAY, was allowed to vary across random blocks (subjects) defined by the Year $\times$ Site combinations. The effect of seismic surveys on catch rates was expected to be dependent upon Site because each site varied with respect to its distance and bearing to the disturbance events. Therefore, the term $B A \times C I$ was interacted with Site to capture these nuances. Ignoring subscripts and parameters, fixed effects for the final model were specified as follows:

$$
\begin{gathered}
C P U E= \\
B A|C I| \text { Site }+ \text { Wind } X \mid \text { Wind } Y+\text { SRD }+ \text { splDAY }
\end{gathered}
$$

where the operator "|" indicates an interaction of two or more terms and all of the corresponding main effects. Each $B A \times C I$ interaction was tested separately for each Site with the "SLICE =" option when estimating and testing the marginal means. All covariates were converted to standard normal deviates (z-scores) before analysis. This specification formed a generalized nonlinear mixed model (GNLMM) for which we estimated the parameters with the GLIMMIX procedure in the statistical software SAS 9.4 (SAS Institute, Inc., 2012). Maximum likelihood was estimated with the Laplace approximation adjusted by the MBN sandwich estimator (SAS Institute, Inc., 2012).

Quantifying Effect Size: The air gun effect was defined as the percent change in the ratio between Control and Impact days during the Historical period (1985-2013) versus 2014, as follows:

SeismicEffect $=\frac{\left(\frac{\text { HistoricalControl }}{2014 \text { Control }} \times 2014 \text { Impact }\right)-\text { HistoricalImpact }}{\text { Historicallmpact }} \times 100$

where variables $=$ estimated marginal mean CPUEs for each of the four $B A \times C I$ level combinations. This formulation compares proportional changes and not their absolute differences. By using the marginal means, all categorical variables can be balanced and all covariates held constant at their averages, so that the seismic effect is as isolated as possible from other sources of variability.

Goodness-of-Fit: The value of inferences from a statistical model's output is related to the model's goodnessof-fit. Standard residual plots can be difficult to interpret during generalized linear modeling of discrete datasets containing lots of zeroes. Therefore, goodness-of-fit tests were carried out according to the recommendations of Lin et al. (2002), whereby the observed moving sums of residuals across the range of the predicted responses were compared to randomized realizations. A poor fit was indicated by a low $p$-value (estimated from the Kolmogorovtype supremum test) and visual deviation of the observed fit from the randomized realizations. The supremum test is essentially a Monte Carlo test whereby random residuals around the predicted value are generated for a number of iterations (in this case, 1000 iterations) by parametrically bootstrapping from an assumed Gaussian distribution, the parameters of which are estimated from the observed residuals. The percentage of these iterations with a maximum absolute residual greater than the maximum for the observed residuals represented the $p$-value. Low $p$-values show areas along the $\mathrm{x}$-continuum that deviated more than expected from chance alone and indicate a misspecification of some sort for that covariate. Residual plots against the predicted value test the adequacy of the link function and overall model specification.

\section{RESULTS}

\section{Fish CPUE, Environmental Conditions, and Recorded Sound Levels}

A total of 82569 fishes were collected during 183.3 netdays of fishing effort in 2014. The CPUE for each species and size class for 2014 was within the range found during the previous 27 years of sampling, except for that of broad whitefish in age class 2, which was the highest on record (Table 2). 
TABLE 2. Catch per unit effort (CPUE) in 2014 and historically. CPUE is normalized to 24 hours of catch effort per net. Statistical analyses focused on the species and size classes shown in bold type.

\begin{tabular}{|c|c|c|c|c|}
\hline Species & Age/length group & 2014 & Historical low & Historical high \\
\hline Arctic cod (Boreogadus saida) & & 40.0 & 0.0 & 1357.8 \\
\hline Pacific herring (Clupea pallasii) & All & 0.0 & 0.0 & 2.4 \\
\hline \multirow[t]{2}{*}{ Arctic cisco (Coregonus autumnalis) } & Age 0 & 0.0 & 0.0 & 362.0 \\
\hline & Age 1+ & 91.1 & 6.3 & 143.4 \\
\hline \multirow[t]{4}{*}{ Broad whitefish (Coregonus nasus) } & Age 0 & 0.2 & 0.0 & 80.3 \\
\hline & Age 1 & 28.2 & 0.4 & 130.8 \\
\hline & Age 2 & 35.1 & 0.1 & 26.3 \\
\hline & Age 3+ & 6.3 & 1.2 & 15.3 \\
\hline \multirow[t]{2}{*}{ Least cisco (Coregonus sardinella) } & $<180 \mathrm{~mm}$ & 9.8 & 0.3 & 70.8 \\
\hline & $\geq 180 \mathrm{~mm}$ & 61.7 & 7.9 & 123.0 \\
\hline Humpback whitefish (Coregonus pidschian) & All & 15.6 & 0.1 & 22.0 \\
\hline Saffron cod (Eleginus gracilis) & All & 34.8 & 0.4 & 77.3 \\
\hline Threespine stickleback (Gasterosteus aculatus) & All & 0.0 & 0.0 & 0.7 \\
\hline Kelp snailfish (Liparis tunicatus) & All & 0.0 & 0.0 & 2.4 \\
\hline Burbot (Lota lota) & All & 0.0 & 0.0 & 1.4 \\
\hline Capelin (Mallotus villosus) & All & 0.0 & 0.0 & 1.6 \\
\hline Fourhorn sculpin (Myoxocephalus quadricornis) & All & 35.5 & 0.0 & 128.5 \\
\hline Pink salmon (Oncorhynchus gorbuscha) & All & 0.0 & 0.0 & 0.1 \\
\hline Rainbow smelt (Osmerus mordax) & All & 27.6 & 0.0 & 64.8 \\
\hline Arctic flounder (Pleuronectes glacialis) & All & 48.7 & 3.5 & 110.8 \\
\hline Round whitefish (Prosopium cylindraceum) & All & 0.7 & 0.1 & 15.6 \\
\hline Ninespine stickleback (Pungitius pungitius) & All & 0.2 & 0.0 & 2.4 \\
\hline \multirow[t]{2}{*}{ Dolly Varden (Salvelinus malma) } & $<350 \mathrm{~mm}$ & 8.3 & 1.6 & 23.1 \\
\hline & $\geq 350 \mathrm{~mm}$ & 4.8 & 0.8 & 11.8 \\
\hline Arctic grayling (Thymallus arcticus) & All & 0.1 & 0.0 & 15.2 \\
\hline
\end{tabular}

TABLE 3. Directional components of average daily wind speeds in $\mathrm{kmh}^{-1}$

\begin{tabular}{lcccc}
\hline \hline & West & East & North & South \\
\hline Historical low wind speeds & 13 & 22 & 11 & 3 \\
Historical high wind speeds & 36 & 46 & 24 & 22 \\
2014 wind speeds & 24 & 44 & 22 & 15 \\
\hline \hline
\end{tabular}

Daily wind speeds in the east-west and north-south components in 2014 were within the range found in previous years (Table 3), as were average wind speeds (Fig. 3). Discharge rates from the Sagavanirktok River in 2014 ranged from 83 to $432 \mathrm{~m}^{3} /$ day, compared to a range of 30 to $821 \mathrm{~m}^{3 /}$ day in previous years.

Air gun arrays were fired a total of 90686 times, with shots occurring on 17 days during the 58-day study period. Sound pressure sensors at the net locations detected only a small fraction of these shots (Table 4). Although attempts were made to measure particle velocity, the particle motion sensors were overwhelmed by surface wave motion of the shallow water. Wave motion manifested itself as clipping, and on occasion as low-frequency noise contaminating the particle motion signals. The low-frequency noise was removed by signal filtering, but signal distortion produced by clipping cannot be mitigated in post-processing; therefore, few data samples remained from which to derive meaningful particle velocity estimates. The unclipped, filtered, particle velocity estimates that did exist rarely occurred during times when air gun pulses were clearly detected on the ASAR and DASAR pressure sensors. In the rare instances when they did coincide, particle velocity levels were too low relative to background noise levels to reliably detect air gun pulses in the particle velocity time series. Consequently, particle velocity measurements are not reported here.

\section{BACI Estimates}

The statistical results based on the adapted BACI experimental design are given in Table 5 for each species and size class included in the analyses. All diagnostic $p$-values indicated good model fits. $P$-values for each net suggest the significance of the interaction term $B A \times C I$, with low $p$-values indicating strong evidence of an interaction. Such interaction indicates that the relationship between 2014 and previous years was different for days with and without air gun activity in 2014, or, in practical terms, that CPUE changed on days with air gun operations. Table 6 gives the effect sizes for each net where the interaction term $p$-value $\leq 0.1$.

Catches decreased in response to seismic disturbance at the westernmost site (Site WW) and increased at the easternmost site (EE). The two middle sites (WE and EW) had mixed results, but CPUE decreased for three of five species and size classes, showing a significant interaction effect at site WE, but increased for seven of nine species and size classes, showing a significant interaction effect at Site EW.

\section{DISCUSSION}

A simple comparison of CPUE data from 2014 and previous years suggests that 2014, despite the presence of a seismic operation, was a normal year. For all species and size classes except age-2 broad whitefish, CPUE was within 


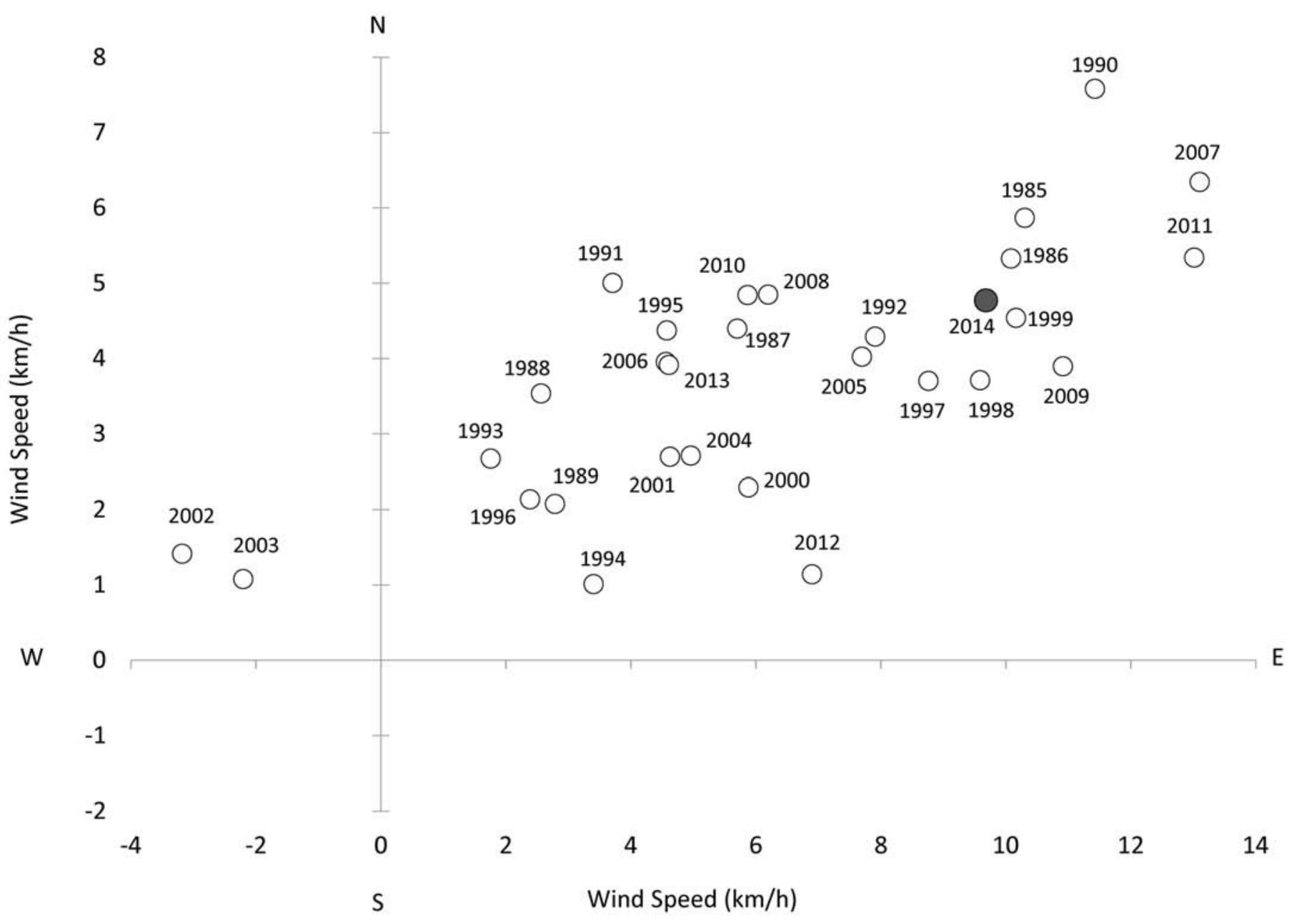

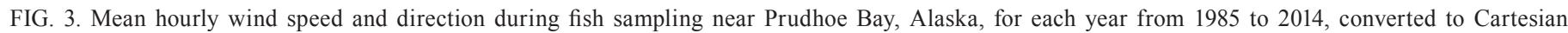
coordinates. Wind data were collected by the National Weather Service at the Deadhorse Airport, Deadhorse, Alaska.

the range of previous years. Age-2 broad whitefish were more abundant in 2014 than in past years, reflecting strong recruitment in 2012 of age- 0 broad whitefish and subsequent record high CPUE for age-1 broad whitefish in 2013. Similarly, 2014 environmental variables fell within the range found in previous years. However, the application of a modified BACI analysis - which in effect allowed a comparison between 2014 and previous years based on expected CPUE for each Julian day, given wind conditions and Sagavanirktok River discharge levels-showed at least some evidence of a response $(p \leq 0.1)$ in CPUE at one or more net locations for all 13 species and size classes assessed. Reasonably strong evidence of a response $(p \leq 0.05)$ was found for 11 of the 13 species and size classes assessed.

Previous studies for other regions or species have also associated fish behavioral responses with air guns. Slotte et al. (2004) reported changes in distribution of pelagic fishes 30 to $50 \mathrm{~km}$ from air gun arrays in the Norwegian Sea. In some cases, reduced CPUE has also been reported. For example, in a field experiment using an air gun to expose rockfish (Sebastes spp.) to sounds with peak pressures up to $186 \mathrm{~dB}$ re $1 \mu \mathrm{Pa}$, Skalski et al. (1992) found a
$52.4 \%$ decrease in CPUE. However, the present study documents change in catch rates in very shallow water and in the Alaskan Arctic for the first time.

The evidence for changes in CPUE found in the current study may be somewhat surprising given the high annual, daily, and spatial variability in CPUE for individual species and size classes routinely collected in the Prudhoe Bay fish monitoring program and the relatively low sound pressure levels received in the vicinity of the fyke nets. The low sound pressure levels received at the fyke nets can be attributed to acoustic propagation characteristics of this shallowwater study site. The shallow water, in conjunction with the relatively large distances between the air gun arrays and the acoustic recorders, resulted in substantial multipath propagation; that is, sound rays repeatedly interacted with the sea surface and seafloor along their propagation paths, reducing sound pressure levels with each interaction. This multipath propagation gave rise to modal dispersion, a spreading in time of the received air gun impulses, as illustrated in Figure 4 for a single air gun pulse (Greene, 1987; Richardson et al., 1995). Additional sound pressure level attenuation was due to the cut-off frequency of shallow-water waveguides, 
TABLE 4. Sound pressure metrics for air gun pulses detected by recorders at each fyke net location in the Alaskan Beaufort Sea during the geophysical survey conducted from 24 July to 25 August 2014.

\begin{tabular}{|c|c|c|c|c|}
\hline \multirow[b]{2}{*}{ Metric } & \multicolumn{4}{|c|}{ Net } \\
\hline & WW & WE & EW & $\mathrm{EE}$ \\
\hline Number of air gun pulses detected & 186 & 5749 & 4215 & 1880 \\
\hline Number of days with air gun pulse detections & 1 & 8 & 6 & 7 \\
\hline $\begin{array}{l}\text { Air gun maximum sound pressure level }\left(\mathrm{SPL}_{\max }\right) \text { : the greatest root-mean- } \\
\text { square sound pressure level of all detected air gun pulses }\end{array}$ & $\begin{array}{l}133.7 \mathrm{~dB} \\
\text { re } 1 \mu \mathrm{Pa}\end{array}$ & $\begin{array}{l}143.8 \mathrm{~dB} \\
\text { re } 1 \mu \mathrm{Pa}\end{array}$ & $\begin{array}{l}114.0 \mathrm{~dB} \\
\text { re } 1 \mu \mathrm{Pa}\end{array}$ & $\begin{array}{l}106.9 \mathrm{~dB} \\
\text { re } 1 \mu \mathrm{Pa}\end{array}$ \\
\hline $\begin{array}{l}\text { Air gun maximum sound exposure level }\left(\mathrm{SEL}_{\mathrm{max}}\right) \text { : the greatest sound } \\
\quad \text { exposure level of all detected air gun pulses }\end{array}$ & $\begin{array}{l}116.2 \mathrm{~dB} \\
\text { re } 1 \mu \mathrm{Pa}^{2}-\mathrm{s}\end{array}$ & $\begin{array}{l}119.8 \mathrm{~dB} \\
\text { re } 1 \mu \mathrm{Pa}^{2}-\mathrm{s}\end{array}$ & $\begin{array}{l}97.9 \mathrm{~dB} \\
\text { re } 1 \mu \mathrm{Pa}^{2}-\mathrm{s}\end{array}$ & $\begin{array}{l}86.2 \mathrm{~dB} \\
\text { re } 1 \mu \mathrm{Pa}^{2}-\mathrm{s}\end{array}$ \\
\hline $\begin{array}{l}\text { Air gun cumulative sound exposure level }\left(\mathrm{SEL}_{\mathrm{cum}}\right) \text { : the sum of SELs of all } \\
\text { detected air gun pulses }\end{array}$ & $\begin{array}{l}125.2 \mathrm{~dB} \\
\text { re } 1 \mu \mathrm{Pa}^{2}-\mathrm{s}\end{array}$ & $\begin{array}{l}140.5 \mathrm{~dB} \\
\text { re } 1 \mu \mathrm{Pa}^{2}-\mathrm{s}\end{array}$ & $\begin{array}{l}125.7 \mathrm{~dB} \\
\text { re } 1 \mu \mathrm{Pa}^{2}-\mathrm{s}\end{array}$ & $\begin{array}{l}111.3 \mathrm{~dB} \\
\text { re } 1 \mu \mathrm{Pa}^{2}-\mathrm{s}\end{array}$ \\
\hline $\begin{array}{l}\text { Air gun equivalent sound level (Leq): } \mathrm{SEL}_{\text {cum }} \text { of all detected air gun pulses } \\
\text { divided by the total duration of all detected air gun pulses }\end{array}$ & $\begin{array}{l}120.8 \mathrm{~dB} \\
\text { re } 1 \mu \mathrm{Pa}\end{array}$ & $\begin{array}{l}122.4 \mathrm{~dB} \\
\text { re } 1 \mu \mathrm{Pa}\end{array}$ & $\begin{array}{l}105.6 \mathrm{~dB} \\
\text { re } 1 \mu \mathrm{Pa}\end{array}$ & $\begin{array}{l}93.9 \mathrm{~dB} \\
\text { re } 1 \mu \mathrm{Pa}\end{array}$ \\
\hline
\end{tabular}

TABLE 5. Summary of analytical results. High diagnostic $p$-values suggest a good fit between modeled and actual data. $P$-values for the interaction term indicate the significance of the air gun effect on CPUE, with $p \leq 0.1$ in bold.

\begin{tabular}{|c|c|c|c|c|c|c|}
\hline \multirow[b]{2}{*}{ Species } & \multirow[b]{2}{*}{ Size class } & \multirow[b]{2}{*}{ Diagnostic $p$-values } & \multicolumn{4}{|c|}{$P$-values for interaction term $B A \times C I$ by net } \\
\hline & & & WW & WE & EW & $\mathrm{EE}$ \\
\hline Arctic cisco (Coregonus autumnalis) & Age $1+$ & 0.818 & 0.062 & 0.983 & 0.096 & 0.245 \\
\hline \multirow[t]{4}{*}{ Broad whitefish (Coregonus nasus) } & Age 0 & 0.354 & 0.992 & 1.000 & 0.163 & 0.020 \\
\hline & Age 1 & 0.885 & 0.141 & 0.018 & 0.118 & 0.001 \\
\hline & Age 2 & 0.996 & 0.000 & 0.000 & 0.000 & 0.000 \\
\hline & Age 3+ & 0.987 & 0.002 & 0.292 & 0.001 & 0.000 \\
\hline \multirow{2}{*}{ Least cisco (Coregonus sardinella) } & $<180 \mathrm{~mm}$ & 0.998 & 0.949 & 0.062 & 0.060 & 0.817 \\
\hline & $\geq 180 \mathrm{~mm}$ & 0.558 & 0.002 & 0.143 & 0.815 & 0.995 \\
\hline Humpback whitefish (Coregonus pidschian) & All & 0.680 & 0.000 & 0.016 & 0.002 & 0.552 \\
\hline Fourhorn sculpin (Myoxocephalus quadricornis) & All & 0.699 & 0.000 & 0.082 & 0.000 & 0.190 \\
\hline Rainbow smelt (Osmerus mordax) & All & 0.874 & 0.194 & 0.913 & 0.017 & 0.500 \\
\hline Arctic flounder (Pleuronectes glacialis) & All & 0.740 & 0.009 & 0.861 & 0.001 & 0.631 \\
\hline \multirow[t]{2}{*}{ Dolly Varden (Salvelinus malma) } & $<350 \mathrm{~mm}$ & 0.768 & 0.004 & 0.649 & 0.913 & 0.189 \\
\hline & $\geq 350 \mathrm{~mm}$ & 0.455 & 0.710 & 0.736 & 0.007 & 0.122 \\
\hline
\end{tabular}

TABLE 6. Estimated percent change in CPUE in the presence of air gun activity at each fyke net location. Negative values indicate a decreased CPUE, while positive values indicate an increased CPUE. Blank cells indicate $p>0.1$.

\begin{tabular}{|c|c|c|c|c|c|}
\hline \multirow[b]{2}{*}{ Species } & \multirow[b]{2}{*}{ Size class } & \multicolumn{4}{|c|}{ Percent change in CPUE due to seismic impact by net } \\
\hline & & WW & WE & EW & $\mathrm{EE}$ \\
\hline Arctic cisco (Coregonus autumnalis) & Age $1+$ & -48 & & 42 & \\
\hline \multirow[t]{4}{*}{ Broad whitefish (Coregonus nasus) } & Age 0 & & & & 534 \\
\hline & Age 1 & & -72 & & 163 \\
\hline & Age 2 & -18 & 69 & 365 & 300 \\
\hline & Age $3+$ & -60 & & 217 & 317 \\
\hline \multirow[t]{2}{*}{ Least cisco (Coregonus sardinella) } & $<180 \mathrm{~mm}$ & & 136 & 252 & \\
\hline & $\geq 180 \mathrm{~mm}$ & -66 & & & \\
\hline Humpback whitefish (Coregonus pidschian) & All & -68 & -41 & -48 & \\
\hline Fourhorn sculpin (Myoxocephalus quadricornis) & All & -78 & -46 & 308 & \\
\hline Rainbow smelt (Osmerus mordax) & All & & & 310 & \\
\hline Arctic flounder (Pleuronectes glacialis) & All & -58 & & 150 & \\
\hline \multirow[t]{2}{*}{ Dolly Varden (Salvelinus malma) } & $<350 \mathrm{~mm}$ & -77 & & & \\
\hline & $\geq 350 \mathrm{~mm}$ & & & -68 & \\
\hline
\end{tabular}

which caused sound energy to propagate directly into the seafloor rather than through the water column (Jensen et al., 2000). Most of the sound energy emitted in an air gun pulse is found at frequencies below about $1 \mathrm{kHz}$, but in the $\sim 1.5 \mathrm{~m}$ water depths at the recorder locations, the measurable sound pressures from frequencies below about $800 \mathrm{~Hz}$ were entirely lost because of the waveguide's cut-off frequency. Furthermore, in many instances sound pressure pulses were not detected at all at the fyke net locations, perhaps because of acoustic shielding by physical barriers such as causeways and islands (see Fig. 1), as well as the sound pressure attenuation mechanisms described above, at times combined with 


\section{Site WW: 29 July 2014, 18:55:45 AKDT}

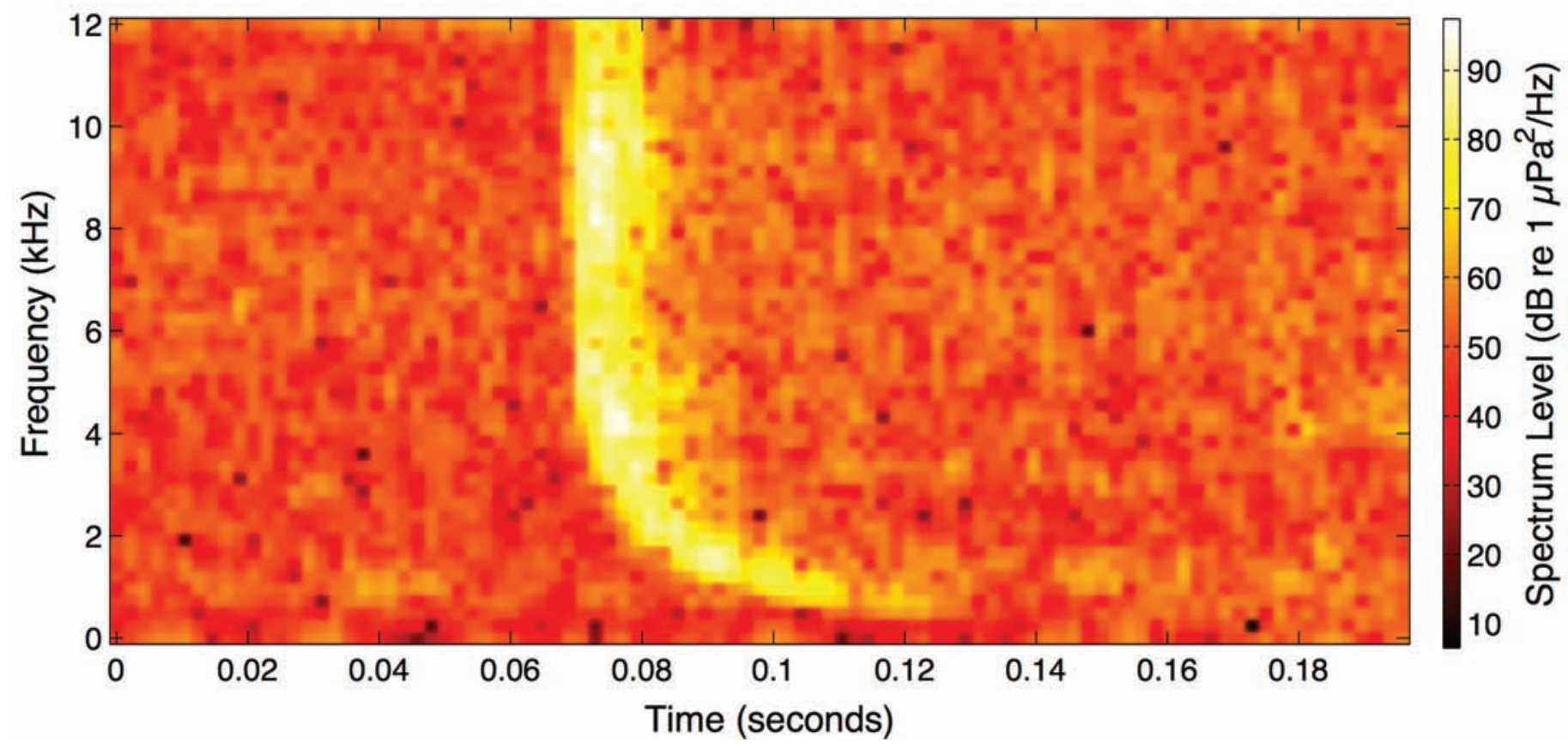

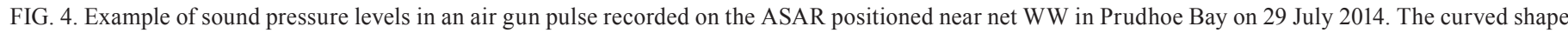

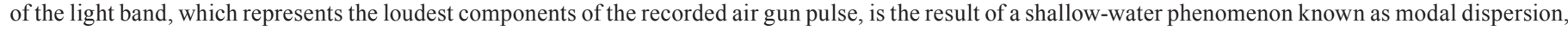

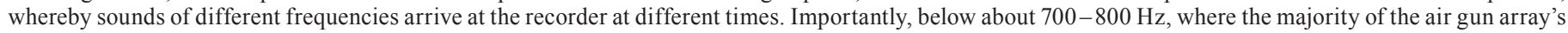
sound energy resides, sound pressure levels associated with air gun pulses are entirely absent in the shallow waters close to the fyke nets.

the masking effects of high ambient noise levels from wind and waves.

Fishes closer to the air gun arrays would have experienced higher sound pressure levels than those measured by ASAR hydrophones near fyke nets. Also, fishes in deeper water would have been exposed to more of the lowfrequency energy of air gun pulses. For example, when air guns were operating in depths of about $16 \mathrm{~m}$, fishes nearby would have been exposed to sound pressures at all frequencies above about $70 \mathrm{~Hz}$ (Jensen et al., 2000).

Although low sound pressure levels were recorded near nets, particle velocities near nets and throughout the study area could have been elevated. Particle velocity measurements using DASARs were overwhelmed, or "clipped," by particle motions associated with wind-driven surface waves in the shallow water of the project area. Although the possibility of significant clipping was raised during study planning, the degree to which it occurred, even under conditions that are typical in Prudhoe Bay during the open water season, was somewhat surprising given the successful use of the DASARs in nearby sites that were slightly deeper (Blackwell et al., 2011; McDonald et al., 2012). If particle motion had been measured with three orthogonally placed sensors, rather than two, measurements may have yielded insights regarding the contribution of the vertical component of particle velocity. The vertical component of sound velocity may have suggested the extent to which propagation across the seabed of air gun-generated Rayleigh waves, or ground roll, contributes to the magnitude of particle velocity in the water column. In future similar efforts, particle velocity measurements should be taken in deeper water to decrease the probability of mechanical (motion-induced) noise and with three orthogonally placed sensors to enable complete characterization of particle velocity.

Studies of other Arctic whitefish (Popper et al., 2005; Mann et al., 2007) and other species that do not possess specializations for enhanced hearing (Popper and Fay, 2011; Popper et al., 2014) suggest that the species captured in this study are probably capable of detecting particle motion in frequencies below about $500 \mathrm{~Hz}$. Although particle velocity associated with air gun shots was not successfully measured, it may have been high enough to influence fish behavior in the vicinity of fyke nets and throughout the study area.

The high daily and annual variability in CPUE hid obvious signs of a response to air guns, but responses became clear through the application of the modified BACI analyses. This analysis was possible only because the long-term data series from the study area was available. In effect, this long-term data series facilitated an understanding of the distribution of CPUE data in the absence of air gun pulses and under various conditions of wind speed, wind direction, and Sagavanirktok River discharge. The 2014 data could be used to identify CPUE levels that were outside of the expected range during days with air gun activity. The models used to quantify seismic impacts yielded high diagnostic $p$-values indicating good model fits, so biased conclusions 
caused by model misspecification were unlikely. If the hydrophones had been positioned in deeper water, and if the recording of particle motion levels in shallow water had been more successful, direct incorporation of sound levels into the model to test their effects might have been possible. Nevertheless, the coarse binary assignment of disturbance to days with and without seismic activity provides evidence of impacts to fish CPUEs, indicating substantial behavioral responses across the entire study area. Although this study cannot directly associate observed changes in CPUE with sound pressure levels or particle velocities, from the results of the BACI analyses it is reasonable to infer that fishes responded to sounds by moving away from air gun arrays. This scenario could explain why nets closest to the disturbance (WW and WE) generally showed decreases in CPUEs and those farther away (EW and EE) showed increases.

At Sites EW and EE, on the eastern half of the operation, significant changes in CPUE were generally increases and often of high magnitude (Table 6). For example, CPUE for broad whitefish in age class 0 increased $534 \%$. One possible explanation for increased catches in the eastern nets is that air gun shots were concentrated to the west of Sites EW and especially EE. For the majority of air gun shots, distances were greatest from Site EE and second greatest from EW, while shorter distances separated air gun shots from Sites WE and WW. Some of the fishes in the project area that moved away from the air gun shots would have been concentrated in the vicinity of Sites EW and EE, leading to increased CPUE. Concentration may have been accentuated by the causeway, which, despite breaches designed to allow fish passage, would to some degree guide fishes toward location EE, where the strongest positive effect on CPUE occurred. Likewise, reduced catches in the westernmost sites (WW and WE) closest to the disturbance support the idea that fishes may have been moving away from nearby air gun operations.

Although the largest changes in CPUE of individual species and size classes occurred at Site EE, CPUE for most species was not significantly changed at Site EE in association with air gun activity. Three of the species without significant responses at this site-fourhorn sculpin (Myoxocephalus quadricornis), rainbow smelt (Osmerus mordax), and Arctic flounder (Pleuronectes glacialis) are nearshore marine species that are less tolerant of low salinities than the other species assessed in BACI analyses, all of which were anadromous or amphidromous. Since the net at Site EE sits close to one of the outflow channels of the Sagavanirktok River, it is plausible that the three marine species were in effect sandwiched between sounds from the north and west and the freshwater discharge from the Sagavanirktok River. Substantial changes in CPUE (150\% to $310 \%$ increases) for these same three marine species at Site EW perhaps reflect the presence of less freshwater discharge.

Not surprisingly, increases and decreases of species and size classes cannot always be conveniently or consistently explained. For example, at the WE net, broad whitefish in age class 1 decreased, while broad whitefish in age class 2 increased. Inconsistencies probably reflect the complex suite of factors that affect fish responses, including uncontrollable factors such as the timing of fish movements relative to the timing of air gun shots. A group of fishes arriving in the project area just before commencement of air gun operations might respond differently than a group of fishes arriving during ongoing air gun operations.

The net impact of seismic disturbance on both the ecology and subsistence fisheries for fishes in and around Prudhoe Bay remains unknown. The current study provides evidence of habitat displacement throughout the seismic exploration project area. Only sound pressure levels were successfully measured in this study, but previous studies suggest that fish responses may have been elicited by changes in particle motion associated with the air gun sounds. While it seems reasonable to assume that habitat displacement had a negative impact on some of the fishes, its importance cannot be established without further research. Likewise, the effect on nearby fisheries cannot be assessed without further research, but air gun activity could increase or decrease catches depending on the locations and timing of the fishing effort and the concurrent seismic surveys using air guns. Nevertheless, this study adds to the growing body of literature implicating air guns in measurable displacement of fishes as indicated by substantial changes in catch rates.

\section{ACKNOWLEDGEMENTS}

This work would not have been possible without the longterm efforts of the late Bob Fechhelm, who led the Prudhoe Bay fish-monitoring program for many years. In 2014, Kyle McCain, Brendon DeVries, Nathan Allton, and Bradley Kalb, all of LGL Ecological Research Associates, Inc., serviced the fyke nets. Alex Conrad of Greeneridge Sciences, Inc., assisted with deployment of acoustic recorders and processed acoustic data. Bill Burgess of Greeneridge Sciences, Inc., assisted with retrieval of acoustic recorders. Kyla Choquette of Swift Worldwide Resources assisted with field logistics coordination, which can often present real challenges in the North Slope oilfields, and reviewed an early version of this manuscript. Larry Wyman of BP Exploration, Alaska, Inc., who managed the seismic operation assessed in this study, was supportive throughout the project. Craig George of the North Slope Borough Department of Wildlife Management provided valuable comments on study design. Lisanne Aerts of LAMA Ecological reviewed an early version of this manuscript. Luisa Alexander Izzo provided excellent copy editing that markedly improved this paper. The authors are grateful to these individuals and many others, including three anonymous reviewers, who provided comments and insights that contributed to the success of this project. 


\section{REFERENCES}

Arab, A., Wildhaber, M.L., Wikle, C.K., and Gentry, C.N. 2008. Zero-inflated modeling of fish catch per unit area resulting from multiple gears: Application to channel catfish and shovelnose sturgeon in the Missouri River. North American Journal of Fisheries Management 28(4):1044-1058. http://dx.doi.org/10.1577/M06-250.1

Blackwell, S.B., McDonald, T.L., Kim, K.H., Aerts, L.A.M., Richardson, W.J., Greene, C.R., Jr., and Streever, B. 2011. Directionality of bowhead whale calls measured with multiple sensors. Marine Mammal Science 28(1):200-212. http://dx.doi.org/10.1111/j.1748-7692.2011.00464.x

Burnham, K.P., and Anderson, D.R. 2002. Model selection and multimodel inference: A practical information-theoretic approach, 2nd ed. New York: Springer-Verlag.

Dunn, M.R. 2009. Review and stock assessment of black cardinalfish (Epigonus telescopus) on the east coast North Island, New Zealand. New Zealand Fisheries Assessment Report 2009/39. Wellington: Ministry of Fisheries.

Engås, A., and Løkkeborg, S. 2002. Effects of seismic shooting and vessel-generated noise on fish behaviour and catch rates. Bioacoustics 12(2-3):313-316.

http://dx.doi.org/10.1080/09524622.2002.9753733

Engås, A., Løkkeborg, S., Ona, E., and Soldal, A.V. 1996. Effects of seismic shooting on local abundance and catch rats of cod (Gadus morhua) and haddock (Melanogrammus aeglefinus). Canadian Journal of Fisheries and Aquatic Sciences 53(10):2238-2249.

http://dx.doi.org/10.1139/f96-177

Greene, C.R., Jr. 1987. Characteristics of oil industry dredge and drilling sounds in the Beaufort Sea. Journal of the Acoustical Society of America 82(4):1315-1324. http://dx.doi.org/10.1121/1.395265

Greene, C.R., Jr., and Richardson, W.J. 1988. Characteristics of marine seismic survey sounds in the Beaufort Sea. Journal of the Acoustical Society of America 83(6):2246-2254. http://dx.doi.org/10.1121/1.396354

Hastings, M.C. 2008. Coming to terms with the effects of ocean noise on marine animals. Acoustics Today 4(2):22-34. http://dx.doi.org/10.1121/1.2961166

Hawkins, A.D., and Popper, A.N. 2014. Assessing the impact of underwater sounds on fishes and other forms of marine life. Acoustics Today 10(2):30-41.

Hawkins, A.D., Roberts, L., and Cheeseman, S. 2014. Responses of free-living coastal pelagic fish to impulsive sounds. Journal of the Acoustical Society of America 135(5):3101-3116. http://dx.doi.org/10.1121/1.4870697

Hawkins, A.D., Pembroke, A.E., and Popper, A.N. 2015. Information gaps in understanding the effects of noise on fishes and invertebrates. Reviews in Fish Biology and Fisheries 25(1):39-64. http://dx.doi.org/10.1007/s11160-014-9369-3

Hazelwood, R.A., and Macey, P.C. 2016. Intrinsic directional information of ground roll waves. In: Popper, A.N., and Hawkins, A., eds. The effects of noise on aquatic life II. New York: Springer Science+Business Media. 447-453. http://dx.doi.org/10.1007/978-1-4939-2981-8_53
Hovem, J.M. 2014. Particle motions caused by seismic interface waves. In: Proceedings of the 37th Scandinavian Symposium on Physical Acoustics, 2-5 February 2014, Geilo, Norway. $1-12$.

Hurlbert, S.H. 1984. Pseudoreplication and the design of ecological field experiments. Ecological Monographs 54(2):187-211. http://dx.doi.org/10.2307/1942661

Kinsler, L.E., Frey, A.R., Coppens, A.B., and Sanders, J.V. 1982. Fundamentals of acoustics. New York: John Wiley \& Sons.

Jensen, F.B., Kuperman, W.A., Porter, M.B., and Schmidt, H. 2000. Computational ocean acoustics. New York: SpringerVerlag.

Lin, D.Y., Wei, L.J., and Ying, Z. 2002. Model-checking techniques based on cumulative residuals. Biometrics 58(1):1-12. http://dx.doi.org/10.1111/j.0006-341X.2002.00001.x

Løkkeborg, S., Ona, E., Vold, A., and Salthaug, A. 2012. Sounds from seismic air guns: Gear- and species-specific effects on catch rates and fish distribution. Canadian Journal of Fisheries and Aquatic Sciences 69(8):1278-1291.

http://dx.doi.org/10.1139/f2012-059

Mann, D.A., Cott, P.A., Hanna, B.W., and Popper, A.N. 2007. Hearing in eight species of northern Canadian freshwater fishes. Journal of Fish Biology 70(1):109-120. http://dx.doi.org/10.1111/j.1095-8649.2006.01279.x

McCain, K.M., and Raborn, S.W. 2015. Year 32 of the long-term monitoring of nearshore Beaufort Sea fishes in the Prudhoe Bay region: 2014 annual report. Report for BP Exploration (Alaska) Inc. by LGL Alaska Research Associates, Inc. BP Exploration (Alaska) Inc., 900 East Benson Boulevard, Anchorage, Alaska 99519.

McCauley, R.D., Fewtrell, J., Duncan, A.J., Jenner, C., Jenner, M.-N., Penrose, J.D., Prince, R.I.T., Adhitya, A., Murdoch, J., and McCabe, K. 2000. Marine seismic surveys - a study of environmental implications. Australian Petroleum Production \& Exploration Association Journal 40:692-706.

McCauley, R.D., Fewtrell, J., and Popper, A.N. 2003. High intensity anthropogenic sound damages fish ears. Journal of the Acoustical Society of America 113(1):638-642.

http://dx.doi.org/10.1121/1.1527962

McDonald, T.L., Richardson, W.J., Greene, C.R., Jr., Blackwell, S.B., Nations, C.S., Nielson, R.M., and Streever, B. 2012. Detecting changes in the distribution of calling bowhead whales exposed to fluctuating anthropogenic sounds. Journal of Cetacean Research and Management 12(1):91-106.

Minami, M., Lennert-Cody, C.E., Gao, W., and Román-Verdesoto, M. 2007. Modeling shark bycatch: The zero-inflated negative binomial regression model with smoothing. Fisheries Research 84(2):210-221.

http://dx.doi.org/10.1016/j.fishres.2006.10.019

Nowacek, D.P., Clark, C.W., Mann, D., Miller, P.J.O., Rosenbaum, H.C., Golden, J.S., Jasny, M., Kraska, J., and Southall, B.L. 2015. Marine seismic surveys and ocean noise: Time for coordinated and prudent planning. Frontiers in Ecology and the Environment 13(7):378-386.

http://dx.doi.org/10.1890/130286 
Pangerc, T., and Theobald, P. 2015. Summary report of NPL workshop on underwater acoustic vector sensing 2014. National Physical Laboratory Report AC 13. Middlesex, United Kingdom: National Physical Laboratory.

Popper, A.N., and Fay, R.R. 2011. Rethinking sound detection by fishes. Hearing Research 273(1-2):25-36.

http://dx.doi.org/10.1016/j.heares.2009.12.023

Popper, A.N., and Hastings, M.C. 2009. The effects of anthropogenic sources of sound on fishes. Journal of Fish Biology 75(3):455-489.

http://dx.doi.org/10.1111/j.1095-8649.2009.02319.x

Popper, A.N., and Hawkins, A.D., eds. 2016. The effects of noise on aquatic life II. New York: Springer Science+Business Media.

Popper, A.N., Smith, M.E., Cott, P.A., Hanna, B.W., MacGillivray, A.O., Austin, M.E., and Mann, D.A. 2005. Effects of exposure to seismic airgun use on hearing of three fish species. Journal of the Acoustical Society of America 117(6):3958-3971.

Popper, A.N., Hawkins, A.D., Fay, R.R., Mann, D.A., Bartol, S., Carlson, T.J., Coombs, S., et al. 2014. Sound exposure guidelines for fishes and sea turtles: A technical report prepared by ANSI-accredited standards committee S3/SC1 and registered with ANSI. ASA S3/SC1.4 TR-2014. Cham, Switzerland: Springer and ASA Press.

Richardson, W.J., Greene, C.R., Jr., Malme, C.I., and Thomson, D.H. 1995. Marine mammals and noise. San Diego: Academic Press.

Rogers, P.H., and Cox, M. 1988. Underwater sound as a biological stimulus. In: Atema, J., Fay, R.R., Popper, A.N., and Tavolga, W.N., eds. Sensory biology of aquatic animals. New York: Springer-Verlag. $131-149$. http://dx.doi.org/10.1007/978-1-4612-3714-3_5

Rogers, P.H., Hawkins, A.D., Popper, A.N., Fay, R.R., and Gray, M.D. 2016. Parvulescu revisited: Small tank acoustics for bioacousticians. In: Popper, A.N., and Hawkins, A.D., eds. The effects of noise on aquatic life II. New York: Springer Science+Business Media. 933-941. http://dx.doi.org/10.1007/978-1-4939-2981-8_115

SAS Institute Inc. 2012. SAS 9.4 product documentation. Cary, North Carolina: SAS Institute Inc.

Shono, H. 2008. Application of the Tweedie distribution to zero-catch data in CPUE analysis. Fisheries Research 93 (1-2):154-162.

http://dx.doi.org/10.1016/j.fishres.2008.03.006
Skalski, J.R., Pearson, W.H., and Malme, C.I. 1992. Effects of sounds from a geophysical survey device on catch-perunit-effort in a hook-and-line fishery for rockfish (Sebastes spp.). Canadian Journal of Fisheries and Aquatic Sciences 49(7):1357- 1365 . http://dx.doi.org/10.1139/f92-151

Slotte, A., Hansen, K., Dalen, J., and Ona, E. 2004. Acoustic mapping of pelagic fish distribution and abundance in relation to a seismic shooting area off the Norwegian west coast. Fisheries Research 67(2):143-150. http://dx.doi.org/10.1016/j.fishres.2003.09.046

Smith, E.P. 2002. BACI design. In: El-Shaarawi, A.H., and Piegorsch, W.W., eds. Encyclopedia of environmetrics, Vol. 1. Chichester, United Kingdom: John Wiley \& Sons, Ltd. $141-148$.

Song, J., Mann, D.A., Cott, P.A., Hanna, B.W., and Popper, A.N. 2008. The inner ears of northern Canadian freshwater fishes following exposure to seismic air gun sounds. Journal of the Acoustical Society of America 124(2):1360-1366. http://dx.doi.org/10.1121/1.2946702

Southall, B.L., Bowles, A.E., Ellison, W.T., Finneran, J.J., Gentry, R.L., Greene, C.R., Jr., Kastak, D., et al. 2007. Marine mammal noise exposure guidelines: Initial scientific recommendations. Aquatic Mammals 33(4):411-521. http://dx.doi.org/10.1578/AM.33.4.2007.411

Stroup, W.W. 2013. Generalized linear mixed models: Modern concepts, methods and applications. Boca Raton, Florida: CRC Press, Taylor \& Francis Group.

Terceiro, M. 2003. The statistical properties of recreational catch rate data for some fish stocks off the northeast U.S. coast. Fishery Bulletin 101(3):653-672.

Underwood, A.J. 1991. Beyond BACI: Experimental designs for detecting human environmental impacts on temporal variations in natural populations. Australian Journal of Marine and Freshwater Research 42(5):569-588.

http://dx.doi.org/10.1071/MF9910569

Wardle, C.S., Carter, T.J., Urquhart, G.G., Johnstone, A.D.F., Ziolkowski, A.M., Hampson, G., and Mackie, D. 2001. Effects of seismic air guns on marine fish. Continental Shelf Research 21(8-10):1005- 1027. http://dx.doi.org/10.1016/S0278-4343(00)00122-9 